\title{
Assessment of the impact of abattoir effluent on the quality of groundwater in a residential area of Omu-Aran, Nigeria
}

\author{
Olugbenga Oluseun Elemile ${ }^{1 *}$, Davids Olorungbon Raphael ${ }^{2}$, David Olugbenga Omole ${ }^{3}$, \\ Elizabeth Omoladun Oloruntoba ${ }^{4}$, Elijah Oluwasegun Ajayi ${ }^{1}$ and Nyore Adams Ohwavborua ${ }^{1}$
}

\begin{abstract}
Background: Water pollution from abattoir effluents may create substantial environmental and public health hazards. Available literature is scanty on the quality of groundwater located near abattoirs in tropical developing countries like Nigeria. This study, therefore, accessed the impact of abattoir activities on the quality of groundwater in Omu-Aran Nigeria.

Methods: A total of eighteen water samples were taken from five privately own wells and one control well located at varying distances and elevations to the abattoir. The physicochemical characteristics of the water were determined using the standard methods. Data were analyzed using descriptive statistics and ANOVA.

Results: The mean values of parameters in the water samples collected from the studied wells ranged from $5.80 \pm 0.20$ to $7.23 \pm 0.55 \mathrm{mg} / \mathrm{L}, 12.0 \pm 1.0$ to $26.0 \pm 2.0 \mathrm{mg} / \mathrm{L}, 0.06 \pm 0.02$ to $0.16 \pm 0.02 \mathrm{mg} / \mathrm{L}$ and $208.0 \pm 24.25$ to $254.67 \pm 12.22 \mathrm{cfu} / \mathrm{mL}$ for dissolved oxygen, biological oxygen demand, lead and total coliforms, respectively. There was a significant difference in the quality of water from the studied and control wells in the parameters except that of total coliform. The quality of the groundwater improved with increasing distance from the abattoir.

Conclusions: Findings revealed that abattoirs have the potential to impact the quality of groundwater. Therefore, careful consideration is required when choosing a location for siting new abattoirs. For existing ones, particularly those close to residential areas, effective pollution control measures should be put in place to protect groundwater.
\end{abstract}

Keywords: Ground water quality, Water pollution, Omu-Aran and abattoir effluents

\section{Introduction}

Water is the most relevant natural resources to the existence of man. Without it nothing would survive on the earth. The volume of water which is available in portable forms is found in water from the ground, springs, rivers and lakes, the proportion of which is only about $3 \%$ [1]. The available water is often inadequate to meet the needs of ever-growing population and industrial demands [1]. It is a common situation in the African continent that majority of the people are living in environments where

\footnotetext{
*Correspondence: elemile.olugbenga@lmu.edu.ng

1 Department of Civil Engineering, Landmark University, Omu-Aran, Nigeria

Full list of author information is available at the end of the article
}

the available water resources do not meet global standard [2]. Groundwater is the commonest potable source around the world [3]. The chemical composition of groundwater is an indicator of how suitable it is for the consumption, for human beings, animals and plants [4]. Water quality refers to the amount of physical impurities, dissolved gases, chemicals, and pathogen in a given sample of water [5]. Human activities impact natural water sources, including groundwater. One of such activities is the indiscriminate location of abattoirs in residential areas in developing countries. The abattoir industry is a vital constituent of the livestock industry because it makes available domestic meat to over 150 million people and makes jobs available for a large number of people in Nigeria [6]. However, the siting of abattoir otherwise 
known as slaughtering house is not often monitored and regulated as expected. Most of the abattoirs in Nigeria are not well developed and facilities for the handling of abattoir solid waste and wastewater are absent. Water pollution from abattoir effluents, runoff from feedlots in dairy farms, grazed pastures, fallow and sod amended with chicken wastes, grassland treated with dairy manure, and sewage sludge leads to contamination of water bodies and could create significant environmental and public health hazards [6]. The main abattoir activities include butchering, removal of the hide, intestine management, rendering, trimming, processing and cleaning activities. The wastes generated from abattoirs usually comprise blood, oil, mineral and organic solids, salts and chemicals added during handling operations [7]. Abattoir wastewater could significantly intensify the amounts of nitrogen, phosphorus, and total solids in the receiving water body [7]. Slaughtering houses are known globally to contaminate the environment either directly or indirectly from their several procedures. The situation is worsened when abattoirs are situated near residential areas and as such the abattoir wastes are disposed in gullies where runoff washes them downhill, thereby contaminating groundwater and nearby streams. Shallow wells in this area are vulnerable to pollution from abattoir activities as the effluents then percolate into the soil and find its way into the aquifer, even though residence is not aware of the health risk as the water appears potable and fit for consumption. Assessing the water quality within the vicinity of abattoirs in residential areas will help to anticipate the impacts on the health of residents who depend solely on the well waters for consumption and other domestic uses. This is also important because most residents in developing countries believe that because water is potable based on physical observations, it has no effects on their health. The study, therefore, intends to assess the water quality parameters of water in the shallow wells located in the vicinity of the Odo-Eran abattoir located in Ile Olupo Street, Omu-Aran to determine the potability of well water.

\section{Materials and methods}

\section{The study area}

Omu-Aran is situated in the southern part of Kwara State, Nigeria. It is located at latitude $8^{\circ} 8^{\prime} 00^{\prime \prime} \mathrm{N}$, longitude $5^{\circ} 6^{\prime} 00^{\prime \prime} \mathrm{E}$ and altitude $564 \mathrm{~m}$ above mean sea level [8]. Omu-Aran has a population of 148,610 according to the 2006 census on a land area of $73.7 \mathrm{~km}^{2}$ [9]. The studied abattoir is located at about $600 \mathrm{~m}$ uphill of the popular Areyin stream. The stream is the recipient of the discharge from watershed within which the abattoir is located. The topography of the site is rolling. The major source of water to the residence of the area is shallow wells which are scattered within the watershed. Wells can be found uphill and downhill of the abattoir site. It is owned and operated privately. An average of seven cows is slaughtered daily, from where vendors come to purchase the meat and other parts to be sold across the town and its suburbs. The abattoir waste is not adequately managed as the heap of bones and cow dung can be seen close to the shallow well which is the water source for the abattoir. The wash water is drained into a nearby gully. Table 1 shows the description of the various sampling points with respect to the distance in meters from the abattoir and georeferencing. The sample collection points were at a distance of 3.7, 13.5, 64.4, 56.3, 61.7 and $167.9 \mathrm{~m}$ from the abattoir for wells $1,2,3,4,5$ and control well, respectively. The points were also at elevations of $537,537,536,534,533$ and $538 \mathrm{~m}$ for wells $1,2,3,4,5$ and control well, respectively. Figure 1 shows the location of sampling points with respect to distance and elevation to the mini abattoir. The control well was chosen because it is at a higher elevation of $538 \mathrm{~m}$ than the abattoir which is at an elevation of $537 \mathrm{~m}$ and is located at a distance of $167.9 \mathrm{~m}$ from the abattoir; this would not allow the pollution of the ground water of the control well by the abattoir activities.

\section{Well water samples collection}

A total of eighteen water samples, consisting of three water samples, were taken from each of the five privately

Table 1 Distance of sampling points from the abattoir with elevation and its coordinates

\begin{tabular}{lccc}
\hline Sampling points & $\begin{array}{l}\text { Distance from abattoir discharge point (in } \\
\text { meters) }\end{array}$ & $\begin{array}{c}\text { Elevation (in meters) } \\
\text { (latitude, longitude) }\end{array}$ & $\begin{array}{l}\text { Location coordinates } \\
\text { Well 1 }\end{array}$ \\
\hline Well 2 & 3.7 & 537 & $808^{\prime} 11.9^{\prime \prime} \mathrm{N}, 5006^{\prime} 18.2^{\prime \prime} \mathrm{E}$ \\
Well 3 & 13.5 & 537 & $8008^{\prime} 11.9^{\prime \prime} \mathrm{N}, 5006^{\prime} 17.7^{\prime \prime} \mathrm{E}$ \\
Well 4 & 64.4 & 536 & $8008^{\prime} 11.9^{\prime \prime} \mathrm{N}, 5006^{\prime} 20.3^{\prime \prime} \mathrm{E}$ \\
Well 5 & 56.3 & 534 & $8008^{\prime} 10.4^{\prime \prime} \mathrm{N}, 5006^{\prime} 19.5^{\prime \prime} \mathrm{E}$ \\
Control well & 61.7 & 533 & $8008^{\prime} 10.0^{\prime \prime} \mathrm{N}, 5006^{\prime} 18.5^{\prime \prime} \mathrm{E}$ \\
\hline
\end{tabular}




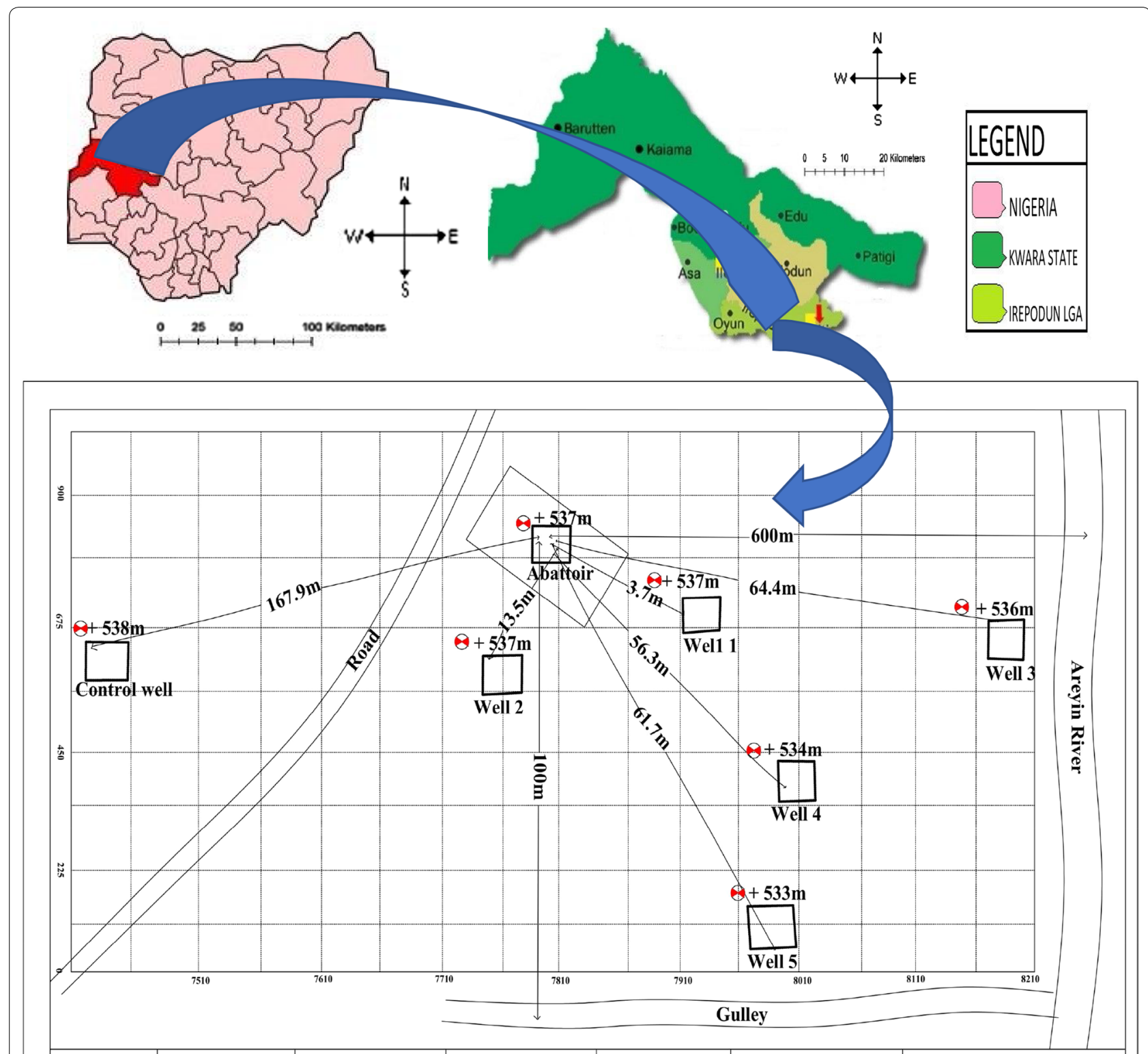

Fig. 1 Map showing the location of the study area and the abattoir

owned wells located in close proximity to the abattoir. Three other samples were collected from a single well at an elevation of $538 \mathrm{~m}$ and a distance of $167.9 \mathrm{~m}$ from the abattoir designated as the control (Fig. 1). The water samples were obtained in the evenings of the first working day of the week, for 3 consecutive weeks during the dry season. Water samples were collected in clean, sterilized $250 \mathrm{~mL}$ glass bottles and kept in a cooler filled with ice cubes. Upon arrival at the laboratory, the samples were preserved in a refrigerator with temperature between 0 and $4{ }^{\circ} \mathrm{C}$, before they were analyzed for selected physicochemical and microbiological parameters. Water samples were also collected in clean, sterilized $750 \mathrm{~mL}$ plastic bottles and labeled appropriately, and were preserved in $5 \% \mathrm{v} / \mathrm{v}$ nitric acid on arrival at the laboratory, where they were analysed for the selected heavy metals. The physicochemical quality of the water samples was determined using the American Public Health Association (APHA) Standard Methods [10]. These parameters included: temperature $(\mathrm{T})$, turbidity (NTU), $\mathrm{pH}$, total alkalinity (TA), total hardness (TH), electrical conductivity (EC), total dissolved solids (TDS), total suspended solids (TSS), dissolved oxygen (DO), biological oxygen demand (BOD), chemical oxygen demand (COD), 
calcium $(\mathrm{Ca})$, magnesium $(\mathrm{Mg})$, sulphate $\left(\mathrm{SO}_{4}\right)$, nitrate $\left(\mathrm{NO}_{3}\right)$, and chloride $(\mathrm{Cl})$. The heavy metal analysis was carried out using hydrochloric acid digestion. Metal ion concentrations were determined using an atomic absorption spectrometer (model Philips PU 9100) with a hollow cathode lamp and a fuel-rich flame (air acetylene). These parameters analyzed included zinc (Zn), nickel (Ni), copper $(\mathrm{Cu})$, chromium $(\mathrm{Cr})$ and lead $(\mathrm{Pb})$. The microbiological analysis of the water samples was performed by the determination of total coliform, according to the modified methods [11].

\section{Data analysis and management}

Data were analyzed using the SPSS software Version 21.0 and the parameters of all the water samples from all the sampling points were compared using ANOVA. Duncan's multiple range comparison tests were used to establish the difference between the average values of parameters that were measured at various wells, using a 5\% significance level $(p<0.05)$. All data obtained were presented as descriptive statistics and compared with the national guideline limits set by the Nigerian Standard for Drinking
Water Quality (NSDWQ) and the World Health Organization (WHO).

\section{Results and discussion \\ Microbial analysis of well water samples Total coliform}

The value for total coliform as shown in Fig. 2 ranged between $208.0 \pm 24.25$ and $254.67 \pm 12.22 \mathrm{cfu} / \mathrm{mL}$ with the water samples from the well 1 having the highest value while well 5 had the lowest value. The values were lower than the values reported elsewhere [12]. There was no significant difference in the values of the total coliform from different wells, although the value of the control well was not the lowest. The presence of coliform indicates growth and possible biofilm contamination. This occurs in both sewage and natural wastes from human and animal feces [12]. The values were all above the WHO value of zero. The results collaborate previous findings elsewhere $[13,14]$. Those studies reported that abattoir effluents are strong pollutants of groundwater regardless of the locations where they are discharged.

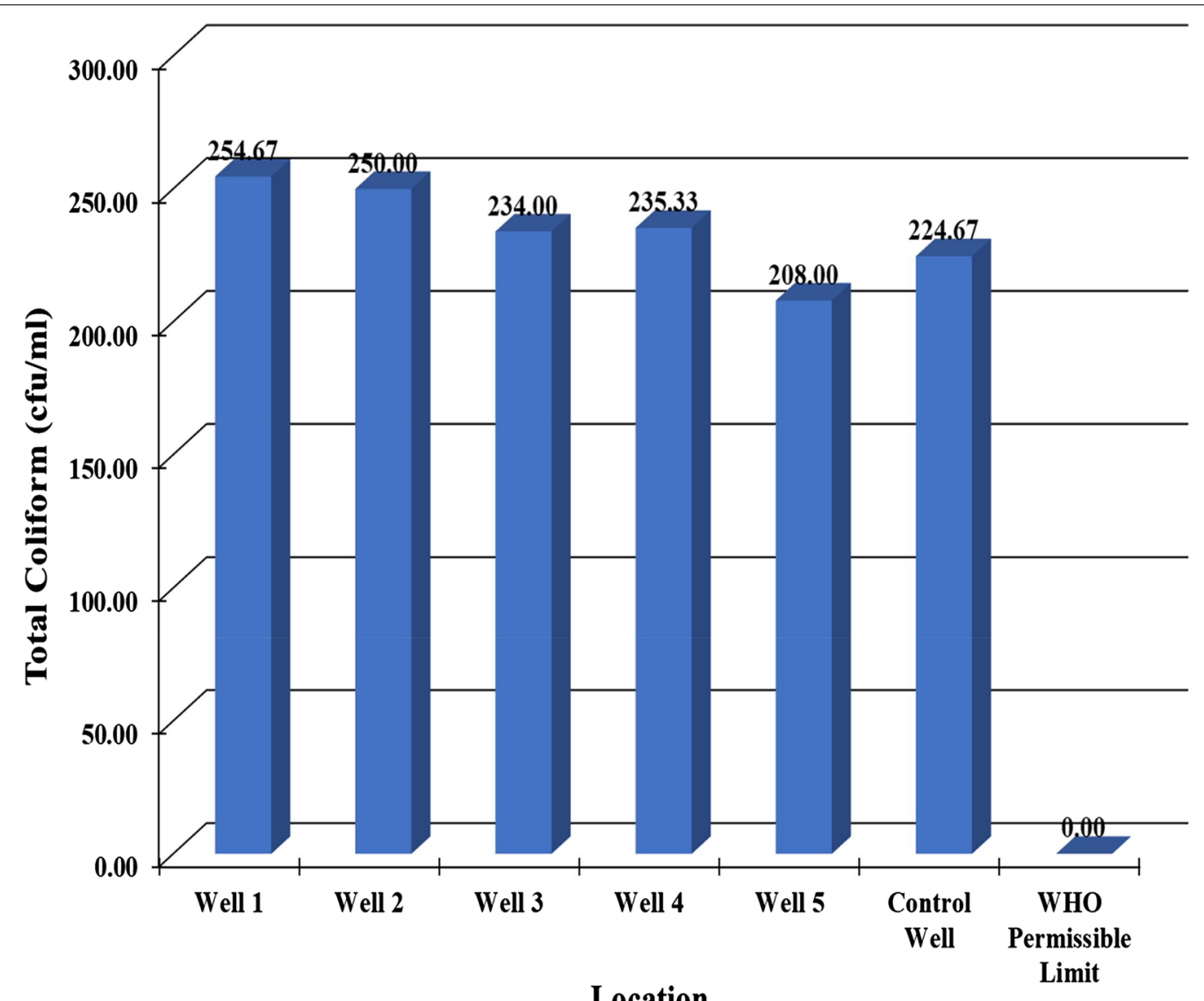

Fig. 2 Total fecal coliform of water samples collected from the sampling points 


\section{Physical analysis of well water samples}

The results of the physicochemical analysis are presented in Table 2.

\section{Temperature}

The temperature of the samples ranged from $26.90 \pm 0.53{ }^{\circ} \mathrm{C}$ to $26.70 \pm 0.66$ with well 4 having the highest values while the value for the control sample was the lowest. The results were slightly lower than that reported by previous studies [12, 15], which reported a range of $27.8-28.3{ }^{\circ} \mathrm{C}$. There is a relationship between ambient temperature and wastewater and groundwater temperature. Omu-Aran is on the hill with annual daily average air temperature ranging from 26 to $28{ }^{\circ} \mathrm{C}$ and yearly variations of $\pm 10-20{ }^{\circ} \mathrm{C}$, so lower temperature is expected. Studies of groundwater of most abattoirs in Nigeria are in the range of $28.5-28.8^{\circ} \mathrm{C}$. Our values were, however, within the WHO standard of the permissible limit of $<40{ }^{\circ} \mathrm{C}$. The parameter is of significant importance because the amount of dissolved oxygen was affected by the temperature which further influences the survival of microorganisms.

\section{$p H$}

The $\mathrm{pH}$ ranged between $6.89 \pm 0.10$ and $7.65 \pm 0.34$ with well 3 having the highest value and the control well having the lowest value. The values were higher when compared with the $\mathrm{pH}$ values of 5.7-6.7 reported elsewhere [16]. There were significant differences in the values of the $\mathrm{pH}$ although the values are, however, within the acceptable limits of the WHO. This is acceptable because the water would unlikely cause ailments such as acidosis [17]. The $\mathrm{pH}$ is an indicator of the presence of microorganisms as it controls their activities [18].

\section{Turbidity}

The turbidity ranged between $0.00 \pm 0.00$ and $2.00 \pm 0.24$ with well 1 having the highest value and the control well having the lowest value. The values were lower when compared with the figures of 115 and 11 reported by [21]. There were no significant differences in the values of turbidity, although the values were within the acceptable limits of the WHO. The difference between the values of the control well and other wells could be ascribed to the distance. This is acceptable because the water would unlikely carry solids which might be responsible for some disease conditions [21].

\section{Electrical conductivity (EC)}

The values of the electrical conductivity ranged between $547.00 \pm 17.00$ and $431.87 \pm 28.31 \mu \mathrm{s} / \mathrm{cm}$ with well $1 \mathrm{hav}-$ ing the highest value of $547.00 \pm 17.00$ with the control well having the lowest value. This is a measure of the dissolved ionic component and total dissolved substitution in water [19]. There were significant differences in the values of the electrical conductivity, although the samples were within the permissible limits of $1000 \mu \mathrm{s} / \mathrm{cm}$ of WHO maximum permissible limits for conductivity. The results indicated that the water samples are not salty as the concentration of salts dissolved in the water is as little as possible. The consumption of the water, which has values above the permissible limits over a period of time, has harmful effects on the health of man as it can defect the endocrine functions and cause total brain damage [12].

\section{Total dissolved solids (TDS)}

The total dissolved solids ranged between $230.00 \pm 10.00$ and $205.00 \pm 5.00 \mathrm{mg} / \mathrm{L}$ with the highest value coming from the water from well 4 , with well 3 having the lowest value. There were significant differences in the values of the TDS of the water samples, although they fall within the permissible limits of $500 \mathrm{mg} / \mathrm{L}$. The implication of a high value of TDS is that the water becomes undrinkable and it can corrode containers used to store water. The high values cannot be attributed to the abattoir but other sources of pollution as the values of the some of the wells were higher than the control well.

Table 2 Physical analysis of water samples collected from the sampling points

\begin{tabular}{|c|c|c|c|c|c|c|c|c|}
\hline \multirow[t]{2}{*}{ Parameters } & \multirow[t]{2}{*}{ Units } & \multicolumn{6}{|c|}{ Sampling points } & \multirow[t]{2}{*}{ WHO [23] } \\
\hline & & Well 1 & Well 2 & Well 3 & Well 4 & Well 5 & Control well & \\
\hline Temperature & ${ }^{\circ} \mathrm{C}$ & $26.87+0.47^{a}$ & $26.80+0.56^{a}$ & $26.73+0.68^{a}$ & $26.90+0.53^{a}$ & $26.83+0.68^{a}$ & $26.70+0.66^{\mathrm{a}}$ & $<40$ \\
\hline $\mathrm{pH}$ & & $6.95+0.10^{\mathrm{a}}$ & $6.92+0.33^{\mathrm{a}}$ & $7.65+0.34^{b}$ & $7.14+0.06^{\mathrm{a}}$ & $7.07+0.64^{\mathrm{a}}$ & $6.89+0.10^{\mathrm{a}}$ & $6.5-8.5$ \\
\hline Turbidity & NTU & $0.00+0.00^{\mathrm{a}}$ & $0.00+0.00^{\mathrm{a}}$ & $1.67+0.06^{\mathrm{a}}$ & $2.00+0.13^{\mathrm{a}}$ & $2.00+0.24^{\mathrm{a}}$ & $0.00+0.00^{\mathrm{a}}$ & \\
\hline Electrical conductivity & $\mu \mathrm{s} / \mathrm{cm}$ & $547.00+17.00^{c}$ & $511.67+69.03^{b c}$ & $431.87+28.31^{a}$ & $469.00+19.16^{a b}$ & $464.00+10.44^{a b}$ & $433.33+38.27^{a}$ & 1000 \\
\hline TDS & $\mathrm{mg} / \mathrm{L}$ & $225.00+5.00^{b}$ & $227.67+8.73^{b c}$ & $205.00+5.00^{\mathrm{a}}$ & $230.00+10.00^{c}$ & $216.67+3.51^{\mathrm{ab}}$ & $225.00+6.00^{b}$ & 500 \\
\hline TSS & $\mathrm{mg} / \mathrm{L}$ & $75.00+2.55^{b}$ & $75.55+1.57^{b}$ & $68.50+2.35^{\mathrm{a}}$ & $76.70+4.55^{b}$ & $72.00+5.00^{a b}$ & $75.00+3.50^{b}$ & 35 \\
\hline
\end{tabular}

For each parameter, means with the different letters (superscripts) are significantly different $(p<0.05)$, using Duncan's multiple range test 


\section{Total suspended solids (TSS)}

The total suspended solid ranged between $76.70 \pm 4.55$ and $75.00 \pm 2.55 \mathrm{mg} / \mathrm{L}$ with the highest values also coming from the water from the well 4 with well 3 having the lowest value. There were significant differences in the values of the TSS and the values far exceeded the permissible limits of $1000 \mathrm{mg} / \mathrm{L}$. The high values cannot be attributed to the abattoir as the values of all the wells, including the control well were within the same range. High TSS may be as a result of the high clay content of the water bearing formation in the area. Omu-Aran falls within the south western schist belt [20].

\section{Chemical analysis of well water samples}

The results of the physicochemical analysis are presented in Table 3.

\section{Total hardness}

From the values obtained from the analysis, the total hardness ranged between $13.50 \pm 1.25$ and $12.70 \pm 1.15$ with well 4 and well 3 having the highest and lowest values, respectively. All the values were within the limits of the WHO permissible limits of $150 \mathrm{mg} / \mathrm{L}$. There was no significant difference in the value of total hardness for all the samples; therefore, the abattoir could not be said to have an impact on the parameter, although abattoir wastewater had been reported to contribute to total hardness values [12].

\section{Dissolved oxygen (DO)}

The value for DO ranged between $7.23 \pm 0.55$ and $5.80 \pm 0.20 \mathrm{mg} / \mathrm{L}$ with the water samples from the control well, having the highest value of $7.23 \pm 0.55$, with well 1 having the lowest value. The values were higher than the values from the study carried out by [21] on a similar abattoir study. The values agree with [22] whose findings showed that there is reduction in the DO level in ground water as one approaches the abattoir and increased in the DO level farther away from the slaughter house. There were significant differences in the values of the DO between the study and control wells. The levels of the DO in both studied and control wells indicate that the degree of pollution by organic matter from the water body is minimal as the concentration is higher than the WHO value of $5.0 \mathrm{mg} / \mathrm{L}$. The implication of this is that the abattoir cannot be said to have affected the quality of water although the value of the DO of the water sample at the control well was higher than those in the vicinity of the abattoir. The reason adduced to this is that since the wells have not been abandoned, with constant fetching of water from them, which enables constant aeration of the wells.

\section{Chemical oxidation demand (COD)}

The value for the COD ranged between $44.67 \pm 17.01$ and $16.67 \pm 1.15 \mathrm{mg} / \mathrm{L}$ with the water samples from well 4 having the highest value of $44.67 \pm 17.01$ with the control well having the lowest value. The values were lower than the values from the study carried out by [12] who monitored similar parameters in an abattoir on different terrains. There were significant differences in the values of the COD between the study and control wells, indicating the presence of chemical oxidants in the water, although the values were within the WHO permissible limits of $1000 \mathrm{mg} / \mathrm{L} \mathrm{[23].} \mathrm{The} \mathrm{implication} \mathrm{of} \mathrm{this} \mathrm{is} \mathrm{that} \mathrm{the} \mathrm{abat-}$ toir impacts the quality of water as the value of the COD of the sampled well with that of the control well lower than those in the vicinity of the abattoir.

\section{Biological oxidation demand (BOD)}

The value for the BOD ranged between $26.00 \pm 2.00$ and $12.00 \pm 1.00 \mathrm{mg} / \mathrm{L}$ with the water samples from well 1

Table 3 Chemical analysis of water samples collected from the sampling points

\begin{tabular}{|c|c|c|c|c|c|c|c|c|}
\hline \multirow[t]{2}{*}{ Parameters } & \multirow[t]{2}{*}{ Units } & \multicolumn{6}{|c|}{ Sampling points } & \multirow[t]{2}{*}{ WHO [23] } \\
\hline & & Well 1 & Well 2 & Well 3 & Well 4 & Well 5 & Control well & \\
\hline Total hardness & $\mathrm{mg} / \mathrm{L}$ & $13.20+1.25^{b}$ & $13.40+1.10^{b}$ & $12.05+1.05^{\mathrm{a}}$ & $13.50+1.25^{b}$ & $12.70+1.15^{a}$ & $13.20+0.58^{b}$ & 150 \\
\hline Dissolved oxygen & $\mathrm{mg} / \mathrm{L}$ & $5.80+0.20^{a}$ & $6.43+0.21^{a b}$ & $6.96+0.57^{b c}$ & $6.47+0.31^{a b c}$ & $6.83+0.45^{b c}$ & $7.23+0.55^{c}$ & 5 \\
\hline COD & mg/L & $36.00+2.00^{b}$ & $36.67+3.06^{b}$ & $43.67+17.67^{b}$ & $44.67+17.01^{b}$ & $35.60+3.17^{b}$ & $16.67+1.15^{\mathrm{a}}$ & 1000 \\
\hline BOD & $\mathrm{mg} / \mathrm{L}$ & $26.00+2.00^{b}$ & $21.00+3.60^{\mathrm{ab}}$ & $24.00+9.54^{b}$ & $24.00+5.29^{b}$ & $17.67+4.51^{\mathrm{ab}}$ & $12.00+1.00^{\mathrm{a}}$ & 0.0 \\
\hline Calcium & $\mathrm{mg} / \mathrm{L}$ & $19.00+1.00^{\mathrm{a}}$ & $18.67+1.52^{\mathrm{a}}$ & $20.67+2.51^{\mathrm{a}}$ & $21.00+2.64^{a}$ & $18.67+2.08^{a}$ & $18.33+2.52^{\mathrm{a}}$ & 75 \\
\hline Magnesium & $\mathrm{mg} / \mathrm{L}$ & $0.53+0.06^{b}$ & $0.57+0.15^{b}$ & $0.40+0.10^{\mathrm{ab}}$ & $0.47+0.15^{\mathrm{ab}}$ & $0.33+0.06^{\mathrm{a}}$ & $0.32+0.03^{\mathrm{a}}$ & 50 \\
\hline Sulphate & mg/L & $13.67+0.58^{b c}$ & $15.00+1.00^{c}$ & $12.67+0.58^{b}$ & $12.65+0.56^{b}$ & $12.33+0.57^{b}$ & $10.67+1.53^{\mathrm{a}}$ & 100 \\
\hline Nitrate & mg/L & $2.50+0.11^{b}$ & $2.61+0.18^{b}$ & $2.52+0.15^{b}$ & $2.58+0.15^{b}$ & $2.71+0.15^{b}$ & $1.93+0.07^{\mathrm{a}}$ & 50 \\
\hline Chloride & $\mathrm{mg} / \mathrm{L}$ & $37.00+1.00^{c}$ & $34.67+3.06^{b c}$ & $35.67+1.53^{c}$ & $34.67+2.31^{b c}$ & $31.33+1.53^{b}$ & $26.67+2.30^{\mathrm{a}}$ & 250 \\
\hline
\end{tabular}

For each parameter, means with the different letters (superscripts) are significantly different $(p<0.05)$, using Duncan's multiple range test 
having the highest value of $26.00 \pm 2.00$ with the control well having the least value. This may be due to the nearness of the wells to the abattoir. There were significant differences in the values of the BOD between the study and control wells, showing that the abattoir has an impact on the water quality as the values were above the WHO permissible limits of $0.0 \mathrm{mg} / \mathrm{L}$ but below FEPA $30 \mathrm{mg} / \mathrm{L}$ limit. The water needs to be treated to avert serious health risk [21].

\section{Calcium}

The value for the calcium ranged between $21.00 \pm 2.64$ and $18.33 \pm 2.52 \mathrm{mg} / \mathrm{L}$ with the water samples from well 4 having the highest value of $21.00 \pm 2.64$ and the least from the control well. The values were higher than the values from the study carried out by [21] on a similar abattoir study. There were significant differences in the values of the calcium between the study and control wells, although the values were within the WHO permissible limits of $75 \mathrm{mg} / \mathrm{L}$.

\section{Sulphate}

The value for the sulphate ranged between $15.00 \pm 1.00$ and $10.67 \pm 1.53 \mathrm{mg} / \mathrm{L}$ with the water samples from well 2 having the highest value of $15.00 \pm 1.00 \mathrm{mg} / \mathrm{L}$ with the control well having the lowest value. There were significant differences in the values of the sulphate between the study and control wells, although it has been reported that there is no guideline value based on human health; however, the recommendation of WHO is that any concentration higher than the permissible limits of $100 \mathrm{mg} / \mathrm{L}$ is termed un-hygienic [12].

\section{Nitrate}

The value for the nitrate ranged between $2.71 \pm 0.15$ and $1.93 \pm 0.07 \mathrm{mg} / \mathrm{L}$ with the water samples from well 5 having the highest value of $2.71 \pm 0.15 \mathrm{mg} / \mathrm{L}$ with the control well having the least value. The values were lower than the values from the study carried out by [2], although the values were within the WHO permissible limits of $50 \mathrm{mg} / \mathrm{L}$. There were significant differences in the values of the nitrate between the study and control wells; it has been reported that high values of nitrate could result in the blue-eye syndrome in little children and pregnant women [24]. Also, high concentrations of nitrate and phosphate could lead to eutrophication [25].

\section{Magnesium}

The values were within the WHO permissible limits of $50 \mathrm{mg} / \mathrm{L}$ with the range between $0.57 \pm 0.15$ and $0.32 \pm 0.03 \mathrm{mg} / \mathrm{L}$ with the water samples from well 2 having the highest value of $0.57 \pm 0.15 \mathrm{mg} / \mathrm{L}$ while the control well had the lowest value. There were significant differences in the values of the magnesium between the study and control wells; it has been reported that high values of magnesium could result in the hardness of water [21]. Nigerian Standard for Drinking Water Quality (NIS 554:2007) recommended magnesium concentration of $0.2 \mathrm{mg} / \mathrm{L}$ in drinking water. Magnesium is a nutritional component for human beings, one of the micro-elements which is accountable for functioning of the membrane, stimulation for the transmission of nerves, construction of muscles and DNA duplication [26].

\section{Chloride}

The value for the chloride ranged between $37.00 \pm 1.00$ and $26.67 \pm 2.30 \mathrm{mg} / \mathrm{L}$ with the water samples from well 1. Chlorides are important in the detection of sewage contamination of groundwater; other sources include storm waters containing road salts, the use of artificial fertilizers, landfill leachates, septic tank waste waters, and animal feeds [14]. The values were higher than the values from the study carried out by [14] although the values fall within the WHO permissible limits of $250 \mathrm{mg} / \mathrm{L}$; there were significant differences in the values of the chloride between the study and control wells. Although chloride ions are harmless at low levels, well water with high concentrations of chloride ions could damage plants if used for gardening or irrigation, and it could also give drinking water an unpleasant taste if consumed [23]. The houses in the study area had scattered sewage contamination sources and slaughter house wash water that the chloride detection could be attributed to.

\section{Heavy metal analysis of well water samples}

The results of the physicochemical analysis are presented in Fig. 3.

\section{Zinc}

The value for the detected zinc ranged between $2.60 \pm 0.10$ and $1.27 \pm 0.15 \mathrm{mg} / \mathrm{L}$ with the water samples from well 2 having the highest value of $2.60 \pm 0.10 \mathrm{mg} / \mathrm{L}$ with the control well having the lowest value. Although the values fall within the WHO permissible limits of $3.0 \mathrm{mg} / \mathrm{L}$, there were significant differences in the values of the zinc between the study and control wells. Zinc may have accumulated from infiltrating rainwater from house roofs in the area. It has been reported that acute zinc harmfulness in people includes nausea, lack of moisture, tiredness, weariness, abdominal pain, inability to coordinate the muscles, and kidney failing to function. Chronic doses of zinc increase the risk of developing deformation of blood cells and could also damage the pancreas [27]. 

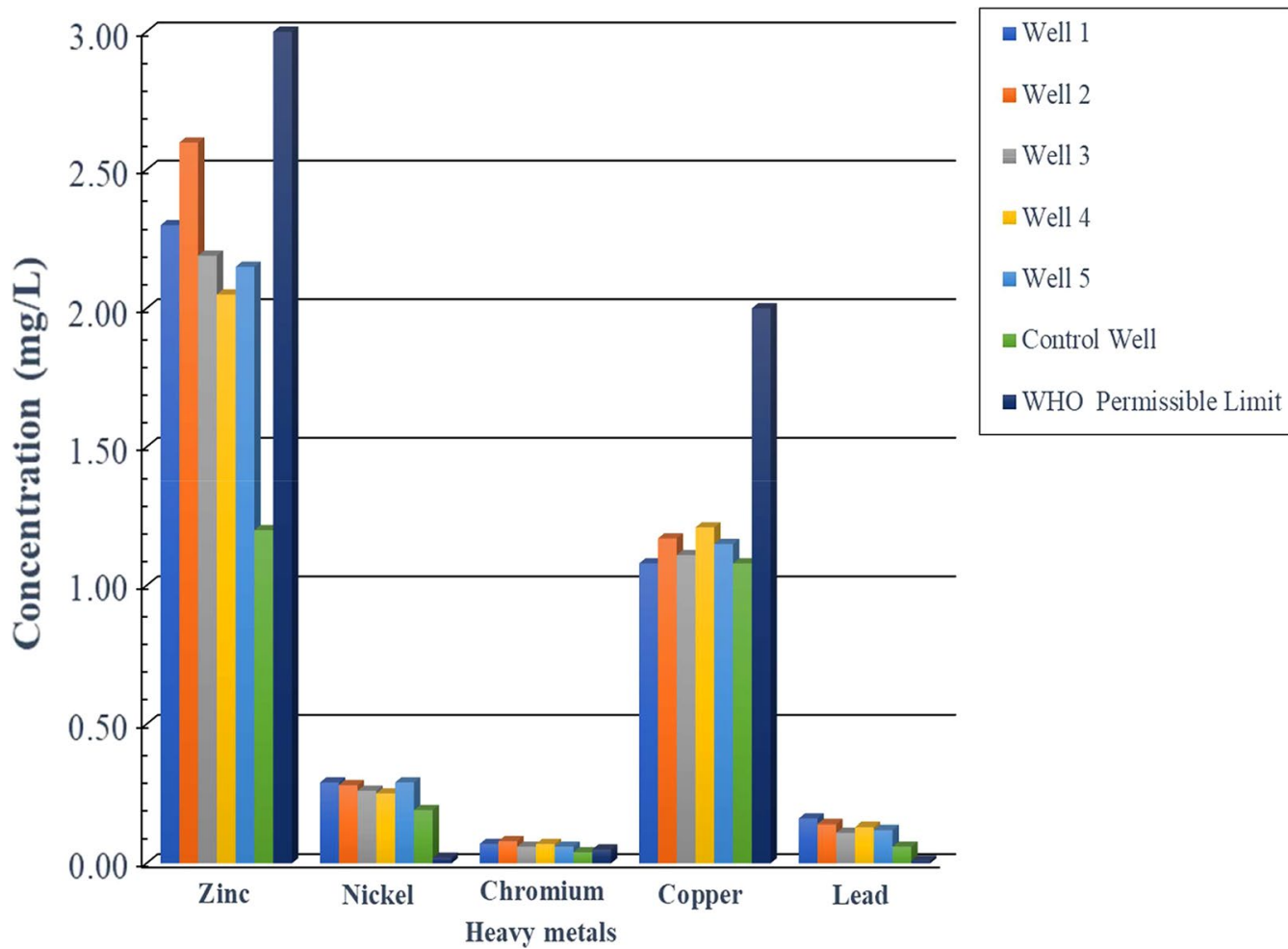

Fig. 3 Heavy metal analysis of water samples collected from the sampling points

\section{Nickel}

The value for the nickel ranged between $0.29 \pm 0.02$ and $0.19 \pm 0.02 \mathrm{mg} / \mathrm{L}$ with the water samples from wells 1 and 5 having the highest value of $0.29 \pm 0.02 \mathrm{mg} / \mathrm{L}$ with the control well having the lowest. The values were higher than the values from the study carried out by [2] and also above the WHO permissible limits of $0.05 \mathrm{mg} / \mathrm{L}$. Nickel gets to the bowels of animal through feeds and water and are passed out with dungs which are washed down the drain and later infiltrates to groundwater. There were significant differences in the values of the nickel between the study and control wells. It is considered as a vital trace metal but poisonous in large quantity making it harmful to human health. It has also been identified as a potential carcinogen of cancer in humans [28].

\section{Chromium}

The value for the chromium ranged between $0.08 \pm 0.00$ and $0.04 \pm 0.00 \mathrm{mg} / \mathrm{L}$ with the water samples from well 2 having the highest value of $0.08 \pm 0.00$ with the control well having the lowest value. The values were above the WHO permissible limits of $0.05 \mathrm{mg} / \mathrm{L}$. There were significant differences in the values of the Chromium between the study and control wells. The pollution of groundwater by chromium could be due to exposure to wastes from chromate-processing amenities which are improperly thrown into open dumps. Incidentally, there is a landfill located at about $100 \mathrm{~m}$ to the mini abattoir where the bones are disposed. The harmful effects of Chromium to human are mostly associated with its hexavalent form. Chromium harmfulness includes liver necrosis and membrane ulcers and is responsible for dermatitis when it has contact with the skin [27].

\section{Copper}

The value for the copper ranged between $1.21 \pm 0.02$ and $1.08 \pm 0.01 \mathrm{mg} / \mathrm{L}$ with the water samples from well 4 having the highest value of $1.21 \pm 0.02 \mathrm{mg} / \mathrm{L}$, with the control well having the lowest value. The values were within the WHO permissible limits of $2.0 \mathrm{mg} / \mathrm{L}$. There were significant differences in the values of the copper between the study and control wells. It has been reported that high values of copper could result in chronic anemia [29]. Copper can contaminate drinking water either by directly polluting well water or through rust of copper pipes and materials.

\section{Lead}

The value for the lead ranged between $0.16 \pm 0.00$ and $0.06 \pm 0.00 \mathrm{mg} / \mathrm{L}$ with the water samples from well 1 having the highest value of $0.16 \pm 0.00 \mathrm{mg} / \mathrm{L}$ with the control well having the lowest value. The values were above 
the WHO permissible limits of $0.015 \mathrm{mg} / \mathrm{L}$. Lead values were higher than the values from the study carried out by [14]. There were significant differences in the values of the lead between the study and control wells. Lead as a contaminant is a well-documented issue. It accrues with time in bones, blood vessels and other internal organs. It can access the human body through the consumption of food, water and air [30]. Lead, aside being a carcinogen, also impacts the central nervous system of the exposed individual and could lead to delayed mental and physical growth in children and could affect the attention span and learning abilities of children [31].

\section{Conclusion}

The study investigated the assessment of the abattoir activities on the groundwater quality in the vicinity of the abattoir in a residential area in Omu-Aran, Nigeria. The pollution impact from the study revealed that the values of the physicochemical parameters in the study wells were higher than those of the control well. There were significant differences in the values of the parameters except total hardness, turbidity and total coliforms. Most of the analyzed parameters except the total coliform, total suspended solids, lead, chromium and nickel were within the recommended limits. The poor quality of water from the studied wells may most likely be due to the nearness of the wells to the abattoir and the effect of the percolation of the abattoir effluents into the soil. This is confirmed by the fact that the parameters of the control well which is farther from the abattoir and at a higher elevation than the study wells had lower values than the study wells which are near the abattoir. Also, the dissolved oxygen was lower in the well nearest the abattoir and was higher as the well got farther from the abattoir. This makes the water from these wells unsuitable for the consumption of humans unless they are appropriately treated, although from physical observations, they seem potable. There is the likelihood for the residents within the vicinity of the abattoir to start to experiencing severe effects of the pollutants from operations of abattoir located in their neighborhood, if adequate treatment and relocation of the mini abattoir are not enforced. It is, therefore, recommended that a pretreatment system should be constructed before the discharge of the waste through a constructed lined drain to the nearby Areyin stream which is about $600 \mathrm{~m}$ away. The discharge of the waste should be done after the segregation of waste materials had been done. In addition, new abattoirs should not be sited in close proximity to residential areas, due to the potential impact on the groundwater quality.

\section{Abbreviations}

WHO: World Health Organization; TSS: total suspended solids; DO: dissolved oxygen; BOD: biochemical oxidation demand; WQI: Water Quality Index; WQS: water quality status; ANOVA: analysis of variance; EC: electrical conductivity; TDS: total dissolved solids; APHA: American Public Health Association; NIS: Nigerian Industrial Standards; SPSS: statistical package for social sciences; COD: chemical oxidation demand; NSDWQ: Nigerian Standard for Water Quality.

\section{Authors' contributions}

OOE: wrote the manuscript. DOR: provided materials. DOO: proof read the manuscript. EOO: data analysis. EOA: laboratory analysis. NAO: collection of the water samples. All authors read and approved the final manuscript.

\section{Author details}

${ }^{1}$ Department of Civil Engineering, Landmark University, Omu-Aran, Nigeria. ${ }^{2}$ Department of Agricultural and Biosystems Engineering, Landmark University, Omu-Aran, Nigeria. ${ }^{3}$ Department of Civil Engineering, Covenant University, Ota, Nigeria. ${ }^{4}$ Department of Environmental Health Sciences, University of Ibadan, Ibadan, Nigeria.

\section{Acknowledgements}

The authors wish to acknowledge Landmark University, Omu-Aran, Nigeria for creating an enabling environment for the conduct of the research work.

\section{Competing interests}

The authors declare that they have no competing interests.

\section{Availability of data and materials}

The materials and data have been made available and submitted as required.

Consent for publication

The authors have given the Journal the Consent to publish the manuscript.

\section{Ethics approval and consent to participate}

There was no form of consent sought during the conduct of the Research as there was no need.

Funding

The authors did not receive any funding from any source.

\section{Publisher's Note}

Springer Nature remains neutral with regard to jurisdictional claims in published maps and institutional affiliations.

Received: 30 October 2018 Accepted: 27 February 2019

Published online: 06 March 2019

\section{References}

1. Behailu TW, Badessa TS, Tewodros BA (2017) Analysis of physical and chemical parameters in ground water used for drinking around Konso Area, Southwestern Ethiopia. J Anal Bioanal Techn 8(5):379. https://doi. org/10.4172/2155-9872.1000379

2. Sawyerr HO, Adedotun AT, Abiodun SA, Salami OO (2017) Impact of dumpsites on the quality of soil and groundwater in satellite towns of the Federal Capital Territory, Abuja, Nigeria. J Health Pollut 7(14):15-21

3. Kanmani S, Gandhimathi R (2013) Investigation of physicochemical characteristics and heavy metal distribution profile in groundwater system around the open dump site. J Appl Water Sci 3:387-399

4. Batabyal AK, Chakraborty S (2015) Hydro geochemistry and water quality index in the assessment of groundwater quality for drinking uses. Water Environ Res. https://doi.org/10.2175/106143015x14212658613956

5. Wurbs RA, James WP (2010) Water resources engineering, 3rd edn. New Delhi India, PHI Learning Private Limited, p 92

6. Nafarnda WD, Ajayi IE, Shawulu JC, Kawe MS, Omeiza GK, Sani NA, Tenuche OZ, Dantong DD, Tags SZ (2012) Bacteriological quality of abattoir effluents discharged into water bodies in Abuja, Nigeria. ISRN Vet Sci. https://doi.org/10.5402/2012/515689 
7. Akange ET, Chaha JA, Odo JI (2016) Impact of Wurukum abattoir effluent on river Benue Nigeria, using macroinvertebrates as bioindicators. Int J Aquac 6(22):1-11. https://doi.org/10.5376/ija.2016.06.0022

8. Raphael OD, Ogedengbe K, Fasinmirin JT, Okunade D, Akande I, Gbadamosi A (2018) Growth-stage-specific crop coefficient and consumptive use of Capsicum chinense using hydraulic weighing lysimeter. Agric Water Manag 2018(203):179-185

9. Vanguard https://www.Vanguardngr.Com/2017/12/Sunset-Noon-Tribu te-Late-lomu-Omu-Aran/. Accessed 18 Dec 2017

10. APHA (2005) Standard methods for the examination of water and wastewater. American Public Health Association, New York, p 46

11. Oyeleke SB, Manga SB (2008) Essentials of laboratory practicals in microbiology. Tobest Publishers, Minna, pp 36-75

12. Yogendra K, Puttaiah ET (2008) Determination of water quality index and suitability of an urban water body in Shimoga Town, Karnataka. In: Proceedings on the 12th World Lake Conference, Jaipur, India. pp 342-346

13. Coker AO, Olugasa BO, Adeyemi AO (2001) Abattoir wastewater quality in South Western Nigeria. In: Proceedings on the 27th WEDC conference, Lusaka, Zambia. pp 329-331

14. Igbinosa IH, Uwidia IE (2018) Effect of abattoir effluents on the physicochemical properties of a receiving watershed in an urban community. Ife J Sci 20(2):219-228

15. Magaji JY, Chup CD (2012) The effects of abattoir waste on water quality in Gwagwalada-Abuja. Ethiop J Environ Stud Manag 5(4):542-549

16. Adelowo OO, Akinlabi IA, Fagade OE (2012) Environmental impact assessment of Attenda abattoir, Ogbomoso southwestern Nigeria on surface and groundwater quality using geo-electrical imaging and microbiological analysis. Environ Monit Assess 84(7):4565-4574

17. Amorin R (2011) Assessment of the quality of bottled/sachet water in the Tarkwa-Nsuaem Municipality (TM) of Ghana. Res J Appl Sci Eng Technol 3:337-385

18. Prescott LM, Harley JP, Klein DA (1999) The influence of environmental factors on growth microbiology, 4th edn. McGraw-Hill Companies Inc., New York, pp 123-132

19. Yilmaz E, Koc C (2014) Physically and chemically evaluation for the water quality criteria in a farm on Akcay. J Water Resourc Protect 2014(6):63-67

20. Kayode JS, Nawawi MNM, Baioumy HM, Khalil AE, Khiruddin BA (2015) Delineation of the subsurface geological structures of Omu-Aran area, south-western Nigeria, using aeromagnetic data. AIP Conf Proc. https:// doi.org/10.1063/1.4915173

21. Chukwu O (2008) Analysis of groundwater pollution from abattoir waste in Minna, Nigeria. Res J Dairy Sci 2(4):74-77

22. Hassan IA, Campbell C, Ademola AG (2014) Effect of abattoir effluent on surrounding underground water quality: a case study of Governor Road Abattoir, Ikotun, Lagos State. Int J Adv Pharm Biol Chem 3(4):957-965

23. WHO (2004) Guideline for drinking water quality, 3rd edn. World Health Organization, Geneva, p 515. ISBN 92-4-154638-7

24. Speijers GJ (1996) Nitrate in toxicological evaluation of certain foot additive and contaminants in food: food additive series 35 . World Health Organization, Geneva, pp 325-360

25. Adeolu AT, Okareh OT, Dada AO (2016) Adsorption of chromium ion from industrial effluent using activated carbon derived from plantain (Musa paradisiaca) wastes. Am J Environ Protect 4(1):7-20. https://doi. org/10.12691/env-4-1-2

26. Bala J, Moumouni A, Musa SS (2016) Influence of abattoir wastes on groundwater quality in Keffi, North Central Nigeria. J Environ Sci Toxicol Food Technol. https://doi.org/10.9790/2402-1010013542

27. Vaishaly AG, Mathew BB, Krishnamurthy NB (2015) Health effects caused by metal contaminated ground water. Int J Adv Sci Res 1(2):60-64

28. Chennaiah JB, Rasheed MA, Patil DJ (2014) Concentration of heavy metals in drinking water with emphasis on human health. Int J Plant Anim Environ Sci 4(2):205-214

29. Iqbal MA, Chaudhary MN, Zaib S, Imran M, Ali K, Iqbal A (2011) Accumulation of heavy metals ( $\mathrm{Ni}, \mathrm{Cu}, \mathrm{Cd}, \mathrm{Cr}, \mathrm{Pb})$ in agricultural soils and spring seasonal plants, irrigated by industrial waste water. J Environ Technol Manag 2:3

30. Nazir R, Khan M, Masab M, Ur Rehman H, Ur Rauf N, Shahab S, Ameer N, Sajed M, Ullah M, Rafeeq M, Shaheen Z (2015) Accumulation of Heavy Metals ( $\mathrm{Ni}, \mathrm{Cu}, \mathrm{Cd}, \mathrm{Cr}, \mathrm{Pb}, \mathrm{Zn}$, Fe) in the soil, water and plants and analysis of physico-chemical parameters of soil and water collected from Tanda Dam kohat. J Pharm Sci Res 7(3):89-97

31. Omole DO, Ogbiye AS, Longe EO, Adewumi IK, Elemile OO, Tenebe TI (2018) Water quality checks on river Atuwara, South-West Nigeria. WIT Trans Ecol Environ 228:165-173

\section{Submit your manuscript to a SpringerOpen ${ }^{\circ}$ journal and benefit from:}

- Convenient online submission

- Rigorous peer review

- Open access: articles freely available online

- High visibility within the field

Retaining the copyright to your article

Submit your next manuscript at springeropen.com 